\title{
PENERAPAN MODEL PEMBELAJARAN NHT BERBANTUAN MEDIA GAMBAR MENINGKATKAN PENGUASAAN KOMPETENSI IPS
}

\author{
Ni Made Dwicahyani ${ }^{1}$, I Wayan Wiarta ${ }^{2}$, I Ketut Ardana ${ }^{3}$ \\ 1,2,3 Jurusan Pendidikan Guru Sekolah Dasar, FIP Universitas Pendidikan Ganesha \\ Singaraja, Indonesia \\ e-mail: a_cahaya@roketmail.co.id
}

\begin{abstract}
ABSTRAK
Penelitian ini bertujuan untuk (1) meningkatkan penguasaan kompetensi pengetahuan IPS melalui penerapan model pembelajaran NHT berbantuan media gambar pada siswa. Jenis penelitian adalah penelitian tindakan kelas yang dilaksanakan dalam dua siklus. Subjek penelitian adalah siswa kelas IV di SDN 2 Pedungan yang berjumlah 46 siswa, terdiri dari 21 orang putra dan 25 orang putri. Data penguasaan kompetensi pengetahuan IPS dikumpulkan dengan metode tes. Data dianalisis dengan metode analisis statistik deskriptif dan analisis deskriptif kuantitatif. Untuk penguasaan kompetensi pengetahuan IPS maka diberikan tindakan dengan menggunakan penerapan model pembelajaran NHT berbantuan media gambar. Pada siklus I didapatkan persentase rata-rata penguasaan kompetensi pengetahuan IPS sebesar $75,65 \%$ dengan kategori B dan persentase ketuntasan klasikal sebesar $43,47 \%$ dengan kategori C. Pada siklus II persentase rata-rata penguasaan kompetensi pengetahuan IPS mengalami peningkatan yaitu $85,80 \%$ dengan kategori B dan ketuntasan klasikal sebesar $84,78 \%$ dengan kategori B. Maka dapat disimpulkan bahwa penerapan model pembelajaran $\mathrm{NHT}$ berbantuan media gambar dapat meningkatkan penguasaan kompetensi pengetahuan IPS siswa kelas IV SDN 2 Pedungan.
\end{abstract}

Kata Kunci : NHT, media gambar, Pembelajaran Saintifik, Kompetensi Pengetahuan IPS.

\begin{abstract}
The purposes of this research are: (1) to improve the mastery of competence IPS knowledge through the application of implementation of learning model NHT media aided drawing in students. The type of this research was classroom action research which was conducted into two cycles. Subjects were students of the fourth grade students of SDN 2 Pedungan and the total of the students were 46 students which consisted of 21 males and 25 females. The data of mastery of competence IPS knowledge was collected using the method of tests. Data were analyzed using descriptive analysis of quantitative and descriptive statistics. To improve the competence of knowledge, the students were given action by using the application of implementation of learning model NHT media aided drawing to the students.

The mastery of competence IPS knowledge students in the first cycle also improved from $76.77 \%$ with the category of good became $85,80 \%$ in the second cycle with the category of good. It can be concluded that the application of implementation of learning model NHT media aided drawing improve the mastery of competence IPS knowledge of the fourth grade students of SDN 2 Pedungan.
\end{abstract}

Keywords : NHT, media images, scientific approach, mastery of competence IPS knowledge. 


\section{Pendahuluan}

Pendidikan menjadi sasaran utama pembangunan. Salah satu upaya untuk meningkatkan kualitas pendidikan adalah dengan perbaikan kurikulum. Kurikulum dalam pasal 1 butir 19 UU Nomor 20 Tahun 2003 tentang Sistem Pendidikan Nasional merupakan seperangkat rencana dan pengaturan mengenai tujuan, isi, dan bahan pelajaran serta cara yang digunakan sebagai pedoman penyelenggaraan kegiatan pembelajaran untuk mencapai tujuan pendidikan tertentu.

Kurikulum yang berlaku saat ini adalah kurikulum 2013. Dalam kurikulum 2013, lebih menekankan pada ketercapaian kompetensi diantaranya kompetensi sikap, pengetahuan, dan keterampilan. Adapun ciri kurikulum 2013 yang paling mendasar ialah menuntut kemampuan guru dalam berpengetahuan dan mencari tahu pengetahuan sebanyak-banyaknya karena siswa zaman sekarang telah mudah mencari informasi dengan bebas melalui perkembangan teknologi dan informasi. Sedangkan untuk siswa lebih didorong untuk memiliki tanggung jawab kepada lingkungan, kemampuan interpersonal, antarpersonal, maupun memiliki kemampuan berpikir kritis. Tujuannya adalah terbentuk generasi produktif, kreatif, inovatif, dan afektif. Pembelajaran dalam kurikulum 2013 adalah pembelajaran tematik terintegrasi. Pembelajaran tematik terintegrasi merupakan pembelajaran dengan menggunakan tema sebagai payung dari setiap muatan materi pembelajarannya.

Kurikulum 2013 dikembangkan dengan penyempurnaan pola pikir, yakni pola pembelajaran yang berpusat pada guru menjadi berpusat pada siswa, pola pembelajaran yang satu arah menjadi pola pembelajaran secara jejaring, pola pembelajaran pasif menjadi pembelajaran aktif-mencari, pola belajar sendiri menjadi pola belajar kelompok, pola pembelajaran ilmu pengetahuan tunggal menjadi pembelajaran ilmu pengetahuan jamak, dan pola pembelajaran pasif menjadi pembelajaran kritis.

Penerapan kurikulum 2013 memerlukan perubahan paradigma pembelajaran, dimana peserta didik dilatih untuk belajar mengobservasi, mengajukan pertanyaan, mengumpulkan data, menganalisis data, dan mengomunikasikan hasil belajar yang disebut pendekatan saintifik. Pendekatan saintifik dimaksudkan untuk memberikan pemahaman kepada peserta didik dalam mengenal, memahami berbagai materi menggunakan pendekatan ilmiah, bahwa informasi bisa berasal dari mana saja, kapan saja, tidak bergantung pada informasi searah dari guru. Pendekatan ini perlu dilakukan untuk dapat mengembangkan kemampuan peserta didik untuk belajar mandiri dan berpikir kreatif.

Ilmu Pengetahuan Sosial (IPS) merupakan salah satu muatan materi yang masuk ke dalam pembelajaran tematik integratif dalam kurikulum 2013. Muatan materi IPS diharapkan dapat menjadi wahana bagi siswa untuk mengembangkan potensi peserta didik agar peka terhadap masalah sosial yang terjadi di masyarakat, memiliki sikap mental positif terhadap perbaikan segala ketimpangan yang terjadi, dan terampil mengatasi setiap masalah yang terjadi sehari-hari baik yang menimpa dirinya sendiri maupun yang menimpa masyarakat.

Berdasarkan hasil wawancara tanggal 21 dan 22 bulan Desember 2015 dengan wali kelas IV yang bernama Ni Made Dina Yanti di lapangan, menyatakan bahwa penguasaan kompetensi pengetahuan IPS siswa kelas IV pada muatan materi IPS masih belum optimal. Data awal penguasaan kompetensi pengetahuan IPS dari 46, 2 siswa yang mendapatkan nilai $A_{-}, 12$ siswa yang mendapatkan nilai $B_{+}, 10$ siswa yang mendapatkan nilai B, 22 siswa yang mendapatkan nilai B-.

Dari permasalahan tersebut maka perlu diupayakan inovasi dalam proses pembelajaran dalam muatan materi IPS dengan menggunakan penerapan model pembelajaran (Number Heads Together) NHT berbantuan media gambar. Menurut Jauhar (2011:62) Model pembelajaran NHT merupakan suatu pendekatan di mana 
setiap siswa diberi nomor kemudian dibuat suatu kelompok kemudian secara acak guru memanggil nomer dari siswa. Menurut Asyhar (2012:57-58) Gambar merupakan media grafis yang paling banyak digunakan. Gambar merupakan hasil lukisan yang menggambarkan orang, tempat dan benda dalam berbagai variasi.

Berdasarkan pemaparan tersebut, maka akan dilaksanakan suatu penelitian tindakan kelas dengan judul Penerapan Model Pembelajaran NHT berbantuan media gambar untuk Meningkatkan Penguasaan Kompetensi Pengetahuan IPS Siswa Kelas IV SD Negeri 2 Pedungan Tahun Pelajaran 2015/2016

\section{Metode}

Penelitian ini digunakan untuk memperbaiki dan meningkatkan penguasaan kompetensi pengetahuan IPS melalui penerapan model pembelajaran NHT berbantuan media gambar. Berdasarkan tujuan tersebut maka rancangan penelitian yang digunakan adalah desain penelitian tindakan kelas. . Menurut Sanjaya (2013:149) "PTK (penelitian tindakan kelas) adalah proses pengkajian masalah pembelajaran di dalam kelas melalui refleksi diri dan upaya untuk memecahkannya dengan cara melakukan berbagai tindakan yang terencana dalam situasi nyata serta menganalisis setiap pengaruh dari tindakan tersebut". Selain itu, menurut Agung (2010:3) PTK (penelitian tindakan kelas) adalah suatu bentuk penelitian yang bersifat reflektif dengan melakukan tindakan-tindakan tertentu agar dapat memperbaiki dan meningkatkan praktek-pratek pembelajaran di kelas secara lebih professional.

Menurut Arikunto (2010:03) penelitian tindakan kelas merupakan suatu proses pencermatan terhadap kegiatan belajar berupa sebuah tindakan yang sengaja dimunculkan dan terjadi dalam sebuah kelas Dapat disimpulkan bahwa PTK merupakan bentuk investigasi reflektif yang dilakukan perorangan maupun kelompok untuk memperbaiki mutu dan meningkatkan kualitas pembelajaran dengan cara yang profesional.

Berdasarkan analisis terhadap permasalahan yang ditemukan, pada penelitian ini dilaksanakan dalam 2 siklus. Adapun tahapan setiap siklus meliputi perencanaan, pelaksanaan, pengamatan, dan refleksi.

Pada setiap siklus dilaksanakan 4 kali pertemuan, yang terdiri dari 3 kali pertemuan untuk pemberian tindakan, dan 1 kali pertemuan untuk tes evaluasi di akhir siklus. Penelitian ini dilaksanakan di SDN 2 Pedungan. Subjek penelitian ini adalah siswa kelas IV SDN 2 Pedungan yang berjumlah 46 siswa. Sedangkan objek penelitian ini adalah penguasaan kompetensi pengetahuan IPS dengan menerapkan model pembelajaran NHT berbantuan media gambar. Metode yang digunakan untuk mengumpulkan data dalam penelitian ini adalah metode observasi atau pengamatan untuk mengumpukan data tentang keaktifan siswa. Metode observasi atau pengamatan (Agung,2010:94) merupakan suatu cara memperoleh data dengan mengadakan pengamatan dan pencatatan secara sistematis tentang suatu objek tertentu. Data dalam penelitian akan dicatat dalam suatu lembar observasi.

Sedangkan data tentang penguasaan kompetensi pengetahuan IPS siswa akan dikumpulkan menggunakan metode tes. Metode tes adalah cara memperoleh data yang berbentuk suatu tugas yang harus dikerjakan oleh seseorang atau kelompok orang yang dites. Dari tes dapat menghasilkan skor yang selanjutnya dibandingkan dengan kriteria tertentu (Agung, 2005:92).

Tes yang digunakan untuk pengumpulan data adalah tes dalam bentuk tes kompetensi pengetahuan IPS. Dengan menggunakan tes dapat diketahui peningkatan penguasaan kompetensi pengetahuan IPS siswa melalui penerapan model pembelajaran NHT berbantuan media gambar. Dalam penelitian ini metode tes dilaksanakan pada setiap akhir siklus dengan menggunakan tes yang telah disesuaikan dengan kisi-kisi tes. Bentuk tes yang digunakan dalam penelitian ini 
adalah tes objektif. Tes objektif yang dipilih adalah tes pilihan ganda biasa berjumlah 30 soal. Tes pilihan ganda cenderung dapat mengungkapkan materi pembelajaran secara luas, karena waktu yang dibutuhkan untuk mengerjakan setiap soal relatif singkat, namun penguasaan materi pembelajaran yang diukur dengan tes objektif pada umumnya lebih terbatas kepada hal - hal yang bersifat faktual.

Data yang telah terkumpul selanjutnya dianalisis dengan metode analisis statistik deskriptif dan analisis deskriptif kuantitatif. Prosedur penelitian tindakan kelas ini dilaksanakan sampai tercapainya penguasaan kompetensi pengetahuan IPS siswa memiliki persentase rata-rata penguasaan kompetensi pengetahuan IPS siswa minimal $75 \%$, berada pada kategori B (71-85) dan ketuntasan klasikal penguasaan kompetensi pengetahuan IPS siswa mencapai kategori minimal $75 \%$ berada pada kategori B (7185).

\section{Hasil dan Pembahasan}

Sesuai dengan permasalahan yang diungkapkan pada bagian pendahuluan, dilaksanakan tindakan dengan menerapkan pendekatan NHT berbantuan media gambar untuk meningkatkan penguasaan kompetensi pengetahuan IPS siswa kelas IV SDN 2 Pedungan tahun pelajaran 2015/2016 dengan jumlah subjek sebanyak 46 orang siswa.

Pada tahap prasiklus dilaksanakan observasi dan pecatatan kompetensi pengetahuan IPS siswa untuk mengetahui keadaan awal siswa pada semester I. Berdasarkan hasil temuan tersebut, terdapat masalah mengenai penguasaan kompetensi pengetahuan IPS siswa yang masih tergolong rendah. Rincian mengenai data tersebut dapat dijelaskan pada Tabel 1.

Tabel 1. Tabel Hasil Refleksi pada Prasiklus Penguasaan Kompetensi Pengetahuan IPS Siswa Kelas IV SDN 2 Pedungan.

\begin{tabular}{|c|c|c|}
\hline Kategori & Hasil & Keterangan \\
\hline $\begin{array}{l}\text { Penguasaan kompetensi } \\
\text { pengetahuan IPS }\end{array}$ & & $\begin{array}{ll}\text { Secara } & \text { umum } \\
\text { penguasaan } & \end{array}$ \\
\hline $\begin{array}{l}\text { a. Persentase rata- } \\
\text { rata }\end{array}$ & $73,08 \%$ & $\begin{array}{l}\text { kompetensi } \\
\text { pengetahuan IPS siswa }\end{array}$ \\
\hline $\begin{array}{l}\text { b. Persentase } \\
\text { ketuntasan klasikal }\end{array}$ & $30,43 \%$ & $\begin{array}{l}\text { masih tergolong dalam } \\
\text { kategori B dengan } \\
\text { ketuntasan } \\
\text { tergolong kategori C }\end{array}$ \\
\hline
\end{tabular}

Presentase rata-rata penguasaan IPS sebelum penelitian adalah $73,08 \%$ yang berada pada kategori B dengan ketuntasan klasikal 30,43\% dengan kategori $C$ yaitu 14 siswa tuntas dan 32 siswa belum tuntas. Pada siklus I proses pembelajaran dilaksanakan sebanyak 4 kali pertemuan, yang terdiri dari 3 kali pertemuan untuk pembelajaran, dan 1 kali pertemuan untuk tes akhir siklus. Hasil penelitian pada siklus I dapat dipaparkan sebagai berikut. 
Tabel 2. Tabel Hasil Tindakan Siklus I Penguasaan Kompetensi Pengetahuan IPS Siswa Kelas IV pada SDN 2 Pedungan.

\begin{tabular}{ccl}
\hline \multicolumn{1}{c}{ Kategori } & Hasil & \multicolumn{2}{c}{ Keterangan } \\
\hline $\begin{array}{l}\text { Penguasaan kompetensi } \\
\text { pengetahuan IPS }\end{array}$ & & $\begin{array}{l}\text { Secara } \\
\text { kompetensi pengetahuan IPS siswa } \\
\text { a. Persentase rata-rata }\end{array}$ \\
b. Ketuntasan klasikal & $75,65 \%$ & $\begin{array}{l}\text { kelas IV berada pada kategori B dan } \\
\text { ketuntasan klasikal berada pada } \\
\text { kategori C }\end{array}$ \\
\hline
\end{tabular}

Berdasarkan pemerolehan data hasil penelitian pada siklus I tersebut, indikator keberhasilan belum tercapai, maka dari itu, penelitian ini perlu dilanjutkan ke siklus II dengan melakukan beberapa penyempurnaan untuk memperoleh hasil yang lebih maksimal dan indikator keberhasilan tercapai. Pada Siklus II ini mengacu pada hasil refleksi siklus I bertujuan untuk memperbaiki proses pembelajaran melalui penerapan model pembelajaran NHT berbantuan Media gambar. Tahapan yang dilakukan pada Siklus II tetap melalui tahap perencanaan, pelaksanaan, observasi, dan refleksi. Hasil penelitian pada siklus II dapat dipaparkan sebagai berikut.

Tabel 3. Tabel Hasil Tindakan Siklus II Penguasaan Kompetensi Pengetahuan IPS Siswa Kelas IV pada SDN 2 Pedungan.

\begin{tabular}{|c|c|c|}
\hline Kategori & Hasil & Keterangan \\
\hline $\begin{array}{l}\text { Penguasaan kompetensi } \\
\text { pengetahuan IPS }\end{array}$ & & \begin{tabular}{lll} 
Secara & umum & \multicolumn{2}{c}{ penguasaan } \\
kompetensi & pengetahuan IPS siswa
\end{tabular} \\
\hline $\begin{array}{l}\text { a. Persentase rata-rata } \\
\text { b. Ketuntasan klasikal }\end{array}$ & $\begin{array}{l}85,80 \% \\
84,78 \%\end{array}$ & $\begin{array}{l}\text { kelas IV berada pada kategori B dan } \\
\text { ketuntasan klasikal berada pada } \\
\text { kategori B }\end{array}$ \\
\hline
\end{tabular}

Berdasarkan pemaparan analisis data siklus 1 dan siklus II, penguasaan kompetensi pengetahuan IPS pada siklus II menunjukkan bahwa persentase rata-rata nilai penguasaan kompetensi pengetahuan IPS siswa sebesar $85,80 \%$ atau berada pada kategori B dengan ketuntasan klasikal sebesar $84,74 \%$ atau berada pada kategori B. Ini berarti sudah adanya peningkatan persentase dari pelaksanaan siklus sebelumnya yang persentase rata-rata penguasaan kompetensi pengetahuan IPS hanya $75,65 \%$ atau berada pada kategori B dengan ketuntasan klasikal hanya $43,47 \%$ atau berada pada kategori C.

Berdasarkan uraikan di atas adanya peningkatan hasil yang diperoleh penguasaan kompetensi pengetahuan IPS siswa pada siklus II sudah mencapai indikator keberhasilan. Artinya penelitian ini dilaksanakan terdiri dari dua siklus yaitu siklus I dan siklus II. Adapun rekapitulasi data penguasaan kompetensi pengetahuan IPS kelas IV SDN 2 Pedungan pada prasiklus, siklus I dan siklus II dapat dilihat pada tabel berikut. 
Tabel 4. Tabel Rekapitulasi Penguasaan Kompetensi Pengetahuan IPS Pra Siklus, Siklus I dan Siklus II.

\begin{tabular}{lll}
\hline Variabel & $\begin{array}{c}\text { Persentase rata-rata penguasaan } \\
\text { kompetensi pengetahuan IPS }\end{array}$ & $\begin{array}{l}\text { Persentase ketuntasan klasikal } \\
\text { penguasaan kompetensi } \\
\text { pengetahuan IPS }\end{array}$ \\
\hline Pra siklus & $73,08 \%$ & $30,43 \%$ \\
Siklus I & $75,65 \%$ & $43,47 \%$ \\
Siklus II & $85,80 \%$ & $84,78 \%$ \\
\hline
\end{tabular}

Berdasarkan rekapitulasi data tersebut, dapat disajikan pada gambar histogram peningkatan persentase rata-rata persentase rata-rata penguasaan kompetensi pengetahuan IPS data sebelum penelitian, siklus I, dan siklus II sebagai berikut.

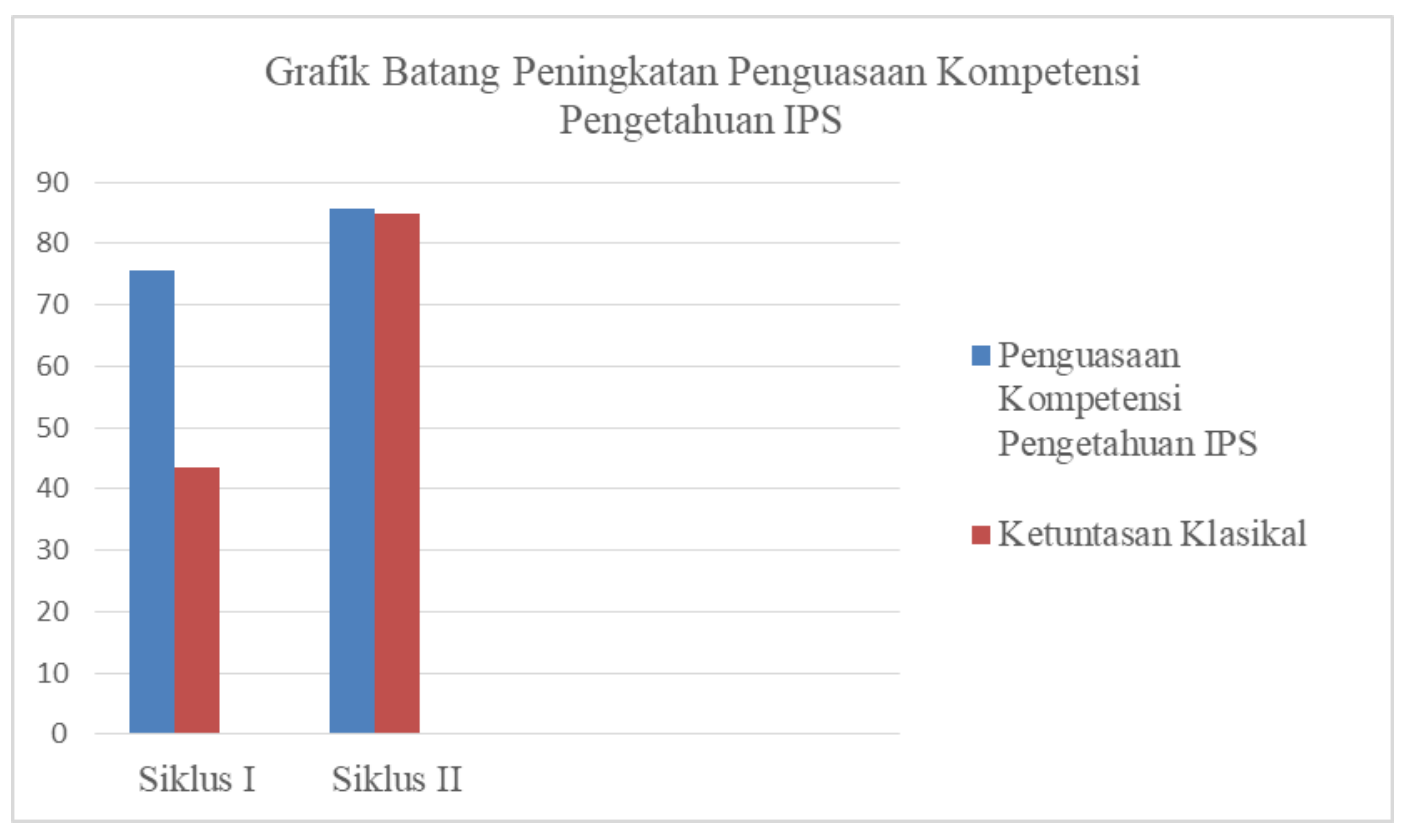

Gambar 1. Grafik Batang Peningkatan Penguasaan Kompetensi Pengetahuan IPS Siswa Kelas IV SDN 2 Pedungan

Berdasarkan tabel dan grafik tersebut, dapat dilihat telah terjadi peningkatan pada penguasaan kompetensi pengetahuan IPS, yaitu pada persentase rata-rata dengan pemberian tindakan melalui penerapan model pembelajaran NHT pada siswa kelas IV SDN 2 Pedungan. Pencapaian dan peningkatan penguasaan kompetensi pengetahuan siswa pada pembelajaran siklus II sudah mencapai indikator keberhasilan dalam penelitian, penguasaan kompetensi pengetahuan IPS siswa berada pada kategori tinggi pada akhir siklus. Dengan demikian, penelitian ini berhasil meningkatkan penguasaan kompetensi pengetahuan IPS siswa kelas IV SDN 2 Pedungan tahun pelajaran 2015/2016. Berdasarkan hal tersebut, maka penelitian ini dihentikan pada siklus II. Sehingga pelaksanaan penelitian ini terdiri dari 2 siklus saja, yaitu siklus I dan siklus II.

Penerapan model pembelajaran NHT berbantuan media gambar di SDN 2 Pedungan yang diterapkan pada siswa kelas IV yang berjumlah 46 siswa sudah berjalan dengan baik dan sesuai dengan perencanaan yaitu untuk mengatasi masalah penguasaan kompetensi pengetahuan IPS siswa. Penelitian ini dilaksanakan dalam dua siklus. Tiap siklus terdapat 4 kali pertemuan. Pertemuan pertama sampai ketiga untuk proses pembelajaran dan pertemuan keempat digunakan untuk mengambil data penguasaan kompetensi pengetahuan 
IPS melalui tes pilihan ganda biasa. Dalam proses pengamatan peneliti dibantu oleh guru kelas dan seorang teman sejawat yang ditunjuk sebagai observer dalam penelitian.

Penerapan model pembelajaran NHT berbantuan media gambar bertujuan untuk meningkatkan penguasaan kompetensi pengetahuan IPS siswa kelas IV SDN 2 Pedungan. Peningkatan terjadi dari siklus I ke siklus II. Hal ini dapat dilihat bahwa pada siklus I dengan rata-rata persentase penguasaan kompetensi pengetahuan IPS siswa mencapai $75,65 \%$ dengan kategori B sesuai dengan Permendikbud No. 53 Tahun 2015 tentang penilaian hasil belajar. Hasil yang diperoleh ini telah memenuhi indikator keberhasilan penguasaan kompetensi pengetahuan IPS yaitu kategori B untuk penguasaan kompetensi pengetahuan IPS namun kategori $\mathrm{C}$ untuk ketuntasan klasikal penguasaan kompetensi pengetahuan IPS siswa. Hal ini disebabkan karena beberapa kendala yang dihadapi pada siklus I. Kendalakendala tersebut, yaitu kurangnya keberanian siswa dalam mengajukan pertanyaan ataupun pendapatnya serta kurang tertibnya siswa dalam mengikuti permainan edukasi , hanya 2 atau 3 orang saja yang aktif berpendapat dalam menyelesaikan masalah. Untuk mengatasi hal ini peneliti dibantu oleh wali kelas IV mengupayakan solusi yang akan digunakan juga sebagai pedoman pada siklus berikutya. Solusi yang diambil yaitu dengan menekankan kembali manfaat pentingnya ketertiban dalam pembelajaran serta melakukan perjanjian antara guru dan siswa ketika siswa tidak tertib. Untuk siswa yang tidak aktif dalam bertanya dan berpendapat, peneliti mendekatkan diri dengan siswa serta memotivasi agar siswa terbuka dan tidak malu lagi dalam menyampaikan pertanyaan dan pendapat.

Hasil refleksi pada siklus I di atas digunakan untuk menentukan tindakan pada siklus II. Dengan menerapkan refleksi tersebut, pada siklus II terjadi peningkatan keaktifan belajar dan penguasaan kompetensi pengetahuan IPS yang signifikan. Persentase rata-rata penguasaan kompetensi pengetahuan IPS mencapai 85,80\% dengan kategori $\mathrm{B}$ dan ketuntasan klasikal mencapai $84,78 \%$ dengan kategori B pada siklus II. Dengan demikian, persentase rata-rata penguasaan kompetensi pengetahuan IPS yaitu minimal $75 \%$ berada pada kategori B serta persentase ketuntasan klasikal penguasaan kompetensi pengetahuan IPS siswa dan minimal $75 \%$ berada pada kategori B. Jadi, secara umum pelaksanaan tindakan siklus I dan siklus II sudah berhasil dan tidak lagi muncul kendala-kendala seperti pada siklus I. Siswa sudah mampu mengikuti pembelajaran dengan mengiplementasikan model pembelajaran NHT berbantuan media gambar. Hal ini terlihat dari kegiatan yang dilakukan siswa dalam mengikuti pembelajaran . Siswa telah percaya diri dalam bertanya dan menyampaikan pendapat. Pada siklus II ini siswa menunjukan keaktifan tinggi dan mampu mengaitkan materi pelajaran yang diberikan dengan pengalaman mereka sehari-hari serta mampu menyimpulkan konsep-konsep yang dipelajari.

Berdasarkan pemaparan di atas, penerapan model pembelajaran NHT berbantuan media gambar dapat meningkatkan penguasaan kompetensi pengetahuan IPS siswa kelas IV SDN 2 Pedungan, hal ini memang dikarenakan memang model pembelajaran NHT berbantuan media gambar sesuai dengan kurikulum 2013 yang menggunakan berbagai tema dalam pembelajarannya, sehingga siswa dapat menggali sendiri informasi mulai dari mengamati hingga mengomunikasikan hasil pengamatannya. Selain itu dengan model pembelajaran NHT berbantuan media gambar berorientasi kepada minat dan energi siswa dapat ditingkatkan dengan menggunakan model pembelajaran NHT. NHT adalah segala usaha yang dilakukan oleh praktisi pendidikan untuk mewujudkan loncatan energi yang ada pada diri setiap peserta didik dengan memperhatikan keterpaduan unsur- unsur belajar sehingga tercapai pembelajaran yang efektif, cepat, dan menyenangkan. Kesenangan dalam pembelajaran dapat diwujudkan dengan media gambar yang dekat dengan dunia siswa.

Berdasarkan uraian di atas dan peningkatkan-peningkatkan yang terjadi pada setiap siklus menunjukan bahwa penerapan model pembelajaran NHT berbantuan media gambar dapat meningkatkan penguasaan kompetensi pengetahuan IPS siswa kelas IV SDN 2 Pedungan tahun pelajaran 2015/2016. 


\section{Simpulan dan Saran}

Berdasarkan hasil penelitian dan pembahasan diatas, maka dapat disimpulkan sebagai berikut.(1) Penerapan model pembelajaran NHT berbantuan media gambar dapat meningkatkan penguasaan kompetensi pengetahuan IPS siswa kelas IV SDN 2 Pedungan tahun pelajaran 2015/2016. Peningkatan ini dapat dilihat dari persentase penguasaan kompetensi pengetahuan IPS siswa pada siklus I sebesar $75,65 \%$ dengan kategori B sedangkan persentase penguasaan kompetensi pengetahuan IPS siswa pada siklus II sebesar $85,80 \%$ dengan kategori B. (2) Penerapan model pembelajaran NHT berbantuan media gambar dapat meningkatkan penguasaan kompetensi pengetahuan IPS siswa kelas IV SDN 2 Pedungan tahun pelajaran 2015/2016. Peningkatan ini dapat dilihat dari ketuntasan klasikal penguasaan kompetensi pengetahuan IPS siswa pada siklus I sebesar $43,37 \%$ dengan kategori C sedangkan ketuntasan klasikal penguasaan kompetensi pengetahuan IPS siswa pada siklus II sebesar $84,78 \%$ dengan kategori B. Berdasarkan simpulan yang diperoleh dalam penilitian tindakan kelas ini diajukan saran-saran sebagai berikut. (1) Disarankan guru agar dapat menerapkan model pembelajaran NHT berbantuan media gambar sehingga tercipta pembelajaran yang kondusif dan menyenangkan sehingga dapat meningkatkan penguasaan kompetensi pengetahuan siswa. (2) Disarankan kepada pihak sekolah untuk memperkenalkan model pembelajaran NHT berbantuan media gambar untuk memperbaiki kualitas serta mutu pendidikan sekolah dasar. (3) Disarankan untuk peneliti lain agar dapat model pembelajaran NHT berbantuan media gambar dengan menyempurnakan langkah-langkah model pembelajaran NHT berbantuan media gambar dan mengaitkannya dengan hal yang dekat dengan siswa

\section{DAFTAR PUSTAKA}

Agung, A. A Gede. 2010. Penelitian Tindakan Kelas. Jakarta: Bumi Aksara

Astrawan, I Gede Budi.2012."Penerapan Model Kooperatif Tipe NHT Dalam Meningkatkan Hasil Belajar Siswa Pada Mata Pelajaran IPA Di Kelas V SD N 3 Tonggolobibi. Jurnal Kreatif Tadulako Online Vol. 3 No. 4ISSN 2354-614X

Asyhar. 2012. Kreatif Mengembangkan Media Pembelajaran. Jakarta : Komplek Megamall

Monawati, M. Yamin. 2016. Upaya Meningkatkan Hasil Belajar Siswa Melalui Lesson Study Pada Penjumlahan Pecahan Di Kelas IV Sdn Lamsayeun. JURNAL PESONA DASAR Universitas Syiah Kuala. Vol. 3 No.4, Oktober.

Mutia Agisni Mulyana, Nurdinah Hanifah, Asep Kurnia Jayadinata. 2016. Penerapan Model Kooperatif Tipe Numbered Heads Together (NHT) Untuk Meningkatkan Hasil Belajar Siswa Pada Materi Kenampakan Alam Dan Sosial Budaya. Jurnal Pena Ilmiah UPI. Vol 1 No 1.

Nursyamsi SY, Aloysius Duran Corebima, Herawati Susilo. 2016. Pengaruh Strategi Pembelajaran Numbered Heads Together (NHT) terhadap Hasil Belajar Siswa SMA Negeri 1 Muara Badak. Jurnal Pendidikan: Teori, Penelitian, dan Pengembangan. Vol 1 No 10 Edisi Oktober.

Pukjiwati. 2017. Upaya Meningkatkan Aktivitas Hasil Belajar Siswa Pada Materi Pecahan Dengan Pendekatan Contextual Teaching and Learning Kelas IV SDN Sumur 03. JURNAL REFLEKSI EDUKATIKA Universitas Muria Kudus. Volume 7 (2). 
Rika Fima Yenni. 2016. Penggunaan Metode Numbered Head Together (NHT) Dalam Pembelajaran Matematika. Jurnal Penelitian dan Pembelajaran Matematika. Jurnal Penelitian dan Pembelajaran Matematika. Vol 9 No 2.

Sanjaya,Wina.2013. Penelitian Pendidikan: Jenis, Metode dan Prosedur. Jakarta: Prenada Media Group.

Susanto, Ahmad. 2013. Teori Belajar dan Pembelajaran di Sekolah Dasar. Jakarta:Kencana Prenada Media Group.

Siti Nuryanti. 2014. Penerapan Model Pembelajaran Kooperatif Tipe Numbered Head Together (Nht) Untuk Meningkatkan Hasil Belajar Siswa Pada Mata Pelajaran Ipa Kelas IV Sd Negeri 3 Tondo. Jurnal Diknas. Volume 2 No 2.

Trianto. 2007. Model-Model Pembelajaran Inovatif Berorientasi Konstruktivistik. Jakarta: Prestasi Pustaka.

Slameto. (2003). Belajar Dan Faktor-Faktor Yang Mempengaruhinya. Jakarta: Rineka Cipta.

Suryanto. (2009). Evaluasi Pembelajaran Di SD. Jakarta: Universitas Terbuka.

Widodo, Lusi Widayanti. 2013. Peningkatan Aktivitas Belajar Dan Hasil Belajar Siswa Dengan Metode Problem Based Learning Pada Siswa Kelas Viia Mts Negeri Donomulyo Kulon Progo. Jurnal Fisika Indonesia No: 49, Vol XVII, Edisi April. 